Check for updates

The BMJ

Cite this as: BMJ2020;370:m3712 http://dx.doi.org/10.1136/bmj.m3712 Published: 22 September 2020

\section{Covid-19: New restrictions to curb rising infection rate are set throughout UK}

Gareth lacobucci

The UK prime minister, Boris Johnson, has set out new national measures designed to halt the current rise in covid-19 cases.

In England, hospitality venues including pubs, bars, and restaurants will have to shut by 10 pm from Thursday 24 September and will be legally permitted only to provide table service, said Johnson.

Face masks will be compulsory for staff in retail, people using taxis, and staff and customers in indoor hospitality-except when they are seated at a table to eat or drink. Fines for breaking these rules will increase. The government is also telling office workers to work from home if they can.

Guidelines for the retail, leisure, tourism, and other sectors will become legal obligations, and the maximum number of people permitted to attend wedding ceremonies and receptions will reduce from 30 to 15 as of Monday 28 September.

The fresh restrictions came after the four UK chief medical officers announced on 21 September that the UK's alert level was being raised from level 3 to level 4, meaning that the virus level was "high or rising exponentially." Some 4368 daily cases were reported in the UK on 21 September, and cases are currently doubling every seven to eight days.

\section{Complacency}

Announcing the changes in the Commons on 22 September after a meeting of the government's COBR emergency committee (popularly known as COBRA), Johnson said that the new measures were likely to be in place for the next six months and were necessary to halt the spread of the virus.

"We always knew that, while we might have driven the virus into retreat, the prospect of a second wave was real. I'm sorry to say that, as in Spain and France and many other countries, we've reached a perilous turning point," he said.

Scotland and Northern Ireland-whose leaders attended the COBR meeting-have both announced that households will be banned from mixing, to drive down infection rates. Wales is expected to announce further national restrictions soon, after already imposing a series of local lockdowns.

Johnson said that it would be a mistake to believe that the threat of covid-19 had disappeared over the six months since the UK-wide national lockdown was imposed.

"That sort of complacency could be our undoing," he said. "If we fail to act together now, we not only put others at risk but jeopardise our own futures with the more drastic action that we will inevitably be forced to take."

But he added that "this is by no means a return to the full lockdown in March," as businesses and schools would remain open and the government was not issuing instructions for everybody to stay at home.

Reacting to the announcement, Saffron Cordery, deputy chief executive of NHS Providers, which represents NHS trusts, said, “As we start to see more people admitted to hospital with covid-19, with a risk that deaths will increase, it is important that we take steps to prevent the spread of the virus.

"No one doubts the impact of these restrictions on people's lives. But the consequences of failing to act and failing to protect the NHS would be even worse." 